\title{
Morphological studies on flowering plants (Solanaceae)
}

\author{
D. Jagatheeswari \\ Department of Botany, Annamalai University, Annamalai Nagar, Chidambaram, Tamil Nadu, India \\ E-mail address: jagatheeswaridurairaj@gmail.com
}

\begin{abstract}
In the present study, the morphological features of 20 taxa of the family Solanaceae were studied. The Solanaceae, or nightshades, are an economically important family of flowering plants. The family ranges from herbs to trees, and includes a number of important agricultural crops, medicinal plants, spices, weeds, and ornamentals. Many members of the family contain potent alkaloids, and some are highly toxic, but many cultures eat nightshades, in some cases as staple foods. The present observation shows that majority of Solanaceae members almost the same morphological features that of the family.
\end{abstract}

Keywords: Night shade family; Solanaceae members; Morphological study; Medicinal plants; Food plants

\section{INTRODUCTION}

The Solanaceae, also called nightshades, comprise more than 3000 species many of which evolved in the Andean/Amazonian regions of South America in habitats that vary dramatically and include rain forests that receive more than 3 meters of rainfall annually to deserts with virtually no rainfall and high mountains with regular snowfall and subfreezing temperatures.

The center of diversity of the Solanaceae is near the equator and thus species were undisturbed by the ice ages and have had time to accumulate adaptive genetic variation for extreme ecological niches. The Solanaceae are also the third most important plant taxon economically and the most valuable in terms of vegetable crops, and are the most variable of crops species in terms of agricultural utility, as it includes the tuber-bearing potato, a number of fruit-bearing vegetables (Tomato, Eggplant, Peppers), ornamental plants (Petunias, Nicotiana), plants with edible leaves (Solanum aethiopicum, S. macrocarpon) and medicinal plants (eg. Datura, Capsicum).

Solanaceaous crops have been subjected to intensive human selection, allowing their use as models to study the evolutionary interface between plants and people. The ancient mode of Solanaceae evolution, coupled with an exceptionally high level of conservation of genome organization at the macro and micro levels make the family a model to explore the basis of phenotypic diversity and adaptation to natural and agricultural environments. 
The Solanaceae include a number of commonly collected or cultivated species. Perhaps the most economically important genus of the family is Solanum, which contains the potato (Solanum tuberosum, in fact, another common name of the family is the "potato family"), the tomato (Solanum lycopersicum), and the aubergine or eggplant (Solanum melongena). Another important genus, Capsicum, produces both chili peppers and bell peppers.

The genus Physalis produces the so-called groundcherries, as well as the tomatillo (Physalis philadelphica), the Cape gooseberry and the Chinese lantern. The genus Lycium contains the boxthorns and the wolfberry Lycium barbarum. Nicotiana contains, among other species, the plant that produces tobacco. Some other important members of Solanaceae include a number of ornamental plants such as Petunia, Browallia and Lycianthes, the source of psychoactive alkaloids, Datura, Mandragora (mandrake), and Atropa belladonna (deadly nightshade). Certain species are universally known for their medicinal uses, their psychotropic effects, or for being poisonous.

With the exception of tobacco (Nicotianoideae) and petunia (Petunioideae), most of the economically important genera are contained in the subfamily Solanoideae. Finally, but not less importantly, the Solanaceae include many model organisms which are important in the investigation of fundamental biological questions at cellular, molecular, and genetic levels, such as tobacco and the petunia.

\section{OBSERVATION}

\section{Brugmansia arborea $\mathbf{L}$.}

Habit: Small wild. Habitat: Mesophyte; in Hill stations at an elevation of 6000 to 8000 feet. Stem: Woody, branched, erect. Leaves: Petiolate, lanceolate, margin entire, alternate. Inflorescence: Solitory and axillary Flowers. Flowers: Pedicelled, Bisexual, actinomorphic, hypogynous, white, pendulous. Calyx: 5 lobes, tubular, entire, acuminate, gamosepalous. Corolla: 5 lobes, tubular, funnel - shaped, very large pendulous,gamopetalous; twisted aestivation. Androecium: 5 Stamens, epipetalous, filaments filiform, anthers distinct, dehiscing longitudinally, inserted. Gynoecium: Bicarpellary, syncarpous, superior ovary; Ovary oblique in position. Many ovules in axile placentation. Fruit: Septifragal capsule.

\section{Cestrum aurentiacum Lindl.}

Habit: Moderate sized wild shrub but usually cultivated. Habitat: Mesophyte at higher elevations of Hill stations up to 8500 feet from MSL. Stem: Woody, erect slightly pubescent. Leaves: Alternate short petiolated oblong lanceolate, slightly pubscent. Inflorescence: Axillary cymes. Flowers: Orange coloured; bisexual actinomorphic. Calyx: 5, sepels; gamosepalous green. Corolla: 5, petals, gamopetalous tubular, orange coloured. Androecium: 5, stamens, epipetalous, equal. Gynoecium: Bicarpellary, syncarpous, superior ovary with axile, placentation. Fruit: Globose berry, yellow. Seeds: White berries.

\section{Capsicum frutescens $\mathrm{L}$.}

Habit: Perennial shrub, cultivated. Habitat: Mesophyte. Stem: Woody, erect, much branched, cylindrical 9 to 18 feet in height. Leaves: Alternate, petiolate, subelliptical, broadly ovate acuminate, $6-12 \mathrm{~cm}$ in long $5-8 \mathrm{~cm}$ in wide. Inflorescence: Axillary and solitary. Flowers: Pedicellate, Bisexual, hypogynous white small in size, actinomorphic. Calyx: 5 lobes, gamosepalous, cup-shaped, embracing the base of fruit. Corolla: 5 lobes, 
gamopetalous, with ocherous markings in the throat. Androecium: 5 stamens, epipetalous, filaments short, anthers about $0.4 \mathrm{~cm}$ long, dehiscing longitudinally. Gynoecium: Bicarpellary, syncarpous, superior ovary with axile placentation, ovary oriented in oblique manner. Fruit: Red, capsule very acrid.

\section{Capsicum annuum $\mathrm{L}$.}

Habit: Perennial herb, cultivated. Habitat: Mesophyte. Stem: Woody, erect, branched, cylindrical, 2.5 to $15 \mathrm{~cm}$ in height. Leaves: Alternate, petiolate, subelliptical, unequal at the base, acuminate. Inflorescence: Axillary and solitary. Flowers: Pedicellate, Bisexual, hypogynous, actinomorphic, white. Calyx: 5 lobes, gamosepalous, persistant. Corolla: 5 lobes, rotate, white; gamopetalous. Androecium: 5, stamens, with bluish anthers, filaments short, anthers about $0.4 \mathrm{~cm}$ long, dehisce longitudinally. Gynoecium: Bicarpellary, syncarpous, superior ovary. The ovary is situated in oblique pattern. Fruit: Pendulous, capsule dark green in colour. About $5 \mathrm{~cm}$ long, $6 \mathrm{~cm}$ in diameter, very acrid.

\section{Datura fastuosa $\mathrm{L}$.}

Habit: Annual herb, wild on wastelands. Habitat: Mesophyte. Stem: Woody branched, erect, and glabrous. Leaves: Petiolate, ovate, acuminate, acute and unequal at the base, wavy, glabrous on both sides. Inflorescence: Solitary and axillary. Flowers: Pedicellated, Bisexual, hypogynous, actinomorphic.white, funnel-shaped and erect. Calyx: 5 lobes, tubular, about 5 $\mathrm{cm}$ long, lanceolate, acuminate, gamosepalous. Corolla: 5, petals, gamopetalous, funnelshaped, the mouth wide white, twisted aestivation. Androecium: 5, stamens, epipetalous, filaments filiform, inserted dehiscing longitudinally about $1.5 \mathrm{~cm}$ long. Gynoecium: Bicarpellary, syncarpous, superior ovary; ovary oblique in position. Ovules many in axile placentation. Fruit: Septifragal capsule.

\section{Datura stramonium L.}

Habit: Pernnial herbs, wild in wastelands. Habitat: Mesophyte. Stem: Woody, branched, cylindrical, glabrous. Leaves: Petiolate, ovate, large acute, base very unequal sided, up to $20 \mathrm{~cm}$ in long, nearly glabrous. Inflorescence: Axillary, solitary. Flowers: Pedicellated, Bisexual, hypogynous, actinomorphic, tubular, funnel-shaped, white tinged with green. Calyx: 5 lobes, gamosepalous, persistant, herbaceous, long-tubular. Corolla: 5, gamopetalous, funnel-shaped, limb plaited, the mouth-wild; twisted aestivation. Androecium: 5, stamens, epipetalous, attached near the base of the tube, filaments filiform, and anthers. $1 \mathrm{~cm}$ long, inserted, dehiscing longitudinally. Gynoecium: Bicarpellary, syncarpous, superior ovary. The ovary is oblique in position. Ovules many in axileplacentation. Fruit: Septifragal capsule.

\section{Lycopersicon esculentum Mill.}

Habit: Herb, cultivated. Habitat: Mesophyte. Stem: Herbaceous, serial branches covered with dense epidermal hairs. Leaves: Alternate, pinnately compound, with small, nearly entire leaf-lets the main leaf-lets notched or even lobed towards the base. Inflorescence: Short raceme Flowers: Pedicellated, Bisexual, small,yellow, hypogynous, rotate actinomorphic. Calyx: 5 lobes, sepals, gamosepalous, persistant. Corolla: 5, petals, gamopetalous, yellow rotate. Androecium: 5, stamens, epipetalous, superior ovary with axile placentation. Gynoecium: Bicarpellary, syncarpous, superior ovary with axile placentation. Fruit: Fleshy, many-seeded berry, furrowed on the sides. 


\section{Lycium ruthenicum Hort.}

Habit: One two or three times branched annual herb. Habitat: Mesophyte, as an escape at Mariappanagar. Stem: Herbaceous when young, woody at maturity; glabrous, cylindrical oblong, lanceolate. Leaves: Alternate simple and glabrous. Inflorescence: Lateral cymes. Flowers: Pedicillate, white, bisexual, actinomorphic, hypogynous. Calyx: 5, sepels; gamosepalouslobes conical. Corolla: 5, petals;white; gamopetalous 0.4 to $0.5 \mathrm{~cm}$ long x 0.2 to $0.3 \mathrm{~cm}$ broad, broadly triangular. Androecium: 5, stamens, epipetalous, opening by terminal pore. Gynoecium: Bicarpellary, syncarpous, superior ovary with axile placentation. The ovary is obliquely oriented. Fruit: Orange yellow berry.

\section{Nicotiana tobaccum $\mathbf{L}$.}

Habit: Tall and erect cultivated large herb. 80 to $100 \mathrm{~cm}$ in height. Habitat: Mesophyte. Stem: Cylindrical, woody, pubescent erect. Leaves: Simple, alternate, ovate; lanceolate, glabrous. Inflorescence: Terminal raceme. Flowers: Pinkish and tubular actinomorphic bisexual. Calyx: 5, gamosepalous; valvate green, persistant. Corolla: 5, gamopetalous, valvate, tubular; pinkish red coloured. Androecium: 5 stamens, epipetalous, equal; dorsifixed. Gynoecium: Bicarpellary, syncarpous, bilocular superior ovary with axile placentation. Fruit: Capsule. Seeds: Minute and brown.

\section{Solanum seaforthianum Andr.}

Habit: Pernnial shrub, climbing on other plants with attractive clusters of blue flowers, wild but sometimes cultivated. Habitat: Found at an elevation of 3000 to 4000 feet at lower elevations of Western Ghats. Also cultivated as an ornamental species in Madras and Pondicherry. Stem: Straggling climber, herbaceous glabrous. Leaves: Simple, alternate, deeply sinuate many lobes, glabrous, 5 inches long x 3 inches broad. Flowers: Axillary cymes, bluish - violet, large, $2.0 \mathrm{~cm}$ in diameter. Calyx: Green, 5 lobes, gamosepalous, glabrous. Corolla: 5 petals, gamopetalous, persistent for a few days. Androecium: 5, stamens, epipetalous. Gynoecium: Bicarpellary, syncarpous, with axile placentation, superior ovary. Fruit: Globose berry, blackish violet 0.8 to $1.0 \mathrm{~cm}$ in diameter.

\section{Solanum sisymbriifolium Lam.}

Habit: A wiscid large herb perennial, wild. Habitat: In W.ghats, Nilgiris and pulneys, at 5000 to 7000 feet. A South American plant. Stem: Herbaceous, straggling with prickles. Leaves: Simple, alternate, sinuately lobed, lobes deep and meany; 8 inches long and 4 inches broad, soft stellate pubescent, prickles very numerous yellowish, straight and sharp in leaves and stem. Flowers: Racemose, white or pale blue, nearly $2 \mathrm{~cm}$. in diameter. Calyx: 5 lobes, gamosepalous with prickles all over the lobes, inflated in fruit deeply cup - shaped ultimately reflexed. Corolla: 5, petals, gamopetalous, white or pale blue. Androecium: 5, stamens, epipetalous. Gynoecium: Bicarpellary, syncarpous, with axile placentation; superior ovary. Fruit: Globose berry, 1.2 to $1.3 \mathrm{~cm}$ inch in diameter, yellow, smooth.

\section{Solanum trilobatum $\mathbf{L}$.}

Habit: Climbing under shrubs, wild, Habitat: Mesophyte Stem: Woody, erect, round with very numerous, short, strong and recurved prickles. Leaves: Alternate, petiolate,obtuse, subcorate at base up to $6 \mathrm{~cm}$. long $3 \mathrm{~cm}$. broad; glabrous few prickles are present on petiole 
and leaves. Inflorescence: Lateral cymes with short peduncles and long pediceles; $2-8$ flowered. Flowers: Pedicellate, bisexual, hypogynous blue, large, actinomorphic. Calyx: 5, lobes ovate, acuminate, persistant, gamosepalous. Corolla: 5, lobes, large, lanceolate, blue about $1.0 \mathrm{~cm}$. long, $0.4 \mathrm{~cm}$. braod gamopetalous. Androceium: 5 anthers, epipetalous, $0.8 \mathrm{~cm}$ long opening with terminal pore. Filaments short about $0.4 \mathrm{~cm}$ long. Gynoecium: Bicarpellary, syncarpous, superior ovary with axile placentation. The ovary is obliquely oriented. Fruit: Globose berry, smooth, scarlet red in colour.

\section{Solanum xanthocarpum Schrad and Wendl.}

Habit: A diffuse perennial conspicuous herb, wild. Habitat: Mesophyte. Stem: Woody branched, creeping. Leaves: Alternate, elliptic, deeply lobed upto $10-12 \mathrm{~cm} \mathrm{long,} 5$ to $6 \mathrm{~cm}$ in broad. Prickles verynumerous, yellow,staright, 1 cmlong on stems, leaves and calyx. Inflorescence: Clustered cymose. Flowers: Pedicellate, bisexual, hypogynous blue or white. Calyx: 5, gamosepalous, lanceolate, with small straight prickles. Corolla: 5, anceolate, gamopetalous, blue or white. Androecium: 5 anthers, epipetalous, $0.5 \mathrm{~cm}$ long opening with terminal pore. Filaments short. Gynoecium: Bicarpellary, syncarpous, superior ovary with axile placentation. The ovary is obliquely oriented. Fruit: Globose berry, yellow or white with green patches.

\section{Solanum nigrum $\mathrm{L}$.}

Habit: A much branched prickly herb, Perennial by dormant root stock, wild. Habitat: Mesophyte. Stem: Woody, erect and much branched, the prickles compressed, stout and sometimes recurved. Leaves: Alternate, ovate, lobed, stellate, woolly beneath and prickly along the nerves. Inflorescence: Lateral Racemes. Flowers: Pedicellate, bisexual, hypogynous, blue, actinomorphic, superior. Calyx: 5, gamosepalous, calyx lobes triangular, acute, very woolly, with slender straight spines. Corolla: $5,3 / 4-1 \mathrm{~cm}$ in diameter, lobes broadly triangular, and gamopetalous. Androecium: 5 anthers, epipetalous, open with terminal pore. Gynoecium: Bicarpellary, syncarpous, superior ovary with axile placentation. The ovary is obliquely oriented. Fruit: Dark yellow berry.

\section{Solanum torvum $\mathbf{L}$.}

Habit: Perennial shrub, often cultivated but sometimes wild also. Habitat: Mesophyte. Stem: Woody, erect and much branched, few prickles are present. Leaves: Alternate, ovate, lobed, acute, often cordate at base, softly tomentose. Inflorescence: A branched helicoids cyme. Flowers: Pedicellate, bisexual, hypogynous,white, actinomorphic. Calyx: 5, gamosepalous, persistant, entire. Corolla: 5 , gamopetalous, rotate, white, $.75 \mathrm{~cm}$ in diameter, stellate. Androecium: 5 anthers, epipetalous, opening with terminal pore, filaments short. Gynoecium: Bicarpellary, syncarpous, superior ovary with obliquely axile placentation. Fruit: A globose berry with many seeds.

\section{Solanum jasminoides Paxt.}

Habit: A straggling wild shrub, perennial, sometimes cultivated as an ornamental plant. Habitat: In hill stations like Ooty and Kodaikanal at an elevation of 6000 to 8500 feet. Stem: Herbaceous, climbing, cylindrical and glabrous. Leaves: Simple, alternate, deeply sinuates glabrous, 5 inches long x 2.5 inches broad. Flowers: Axillary cymes, white. Calyx: 5 sepals, gamosepalous, green. Corolla: 5 petals, gamopetalous white; 1.5 to $2.0 \mathrm{~cm}$ in diameter. 
Androecium: 5 stamens; epipetalous. Gynoecium: Bicarpellary, syncarpous, superior ovary with axile placentation. Fruit: Globose berry, bluish black 0.6 to $0.75 \mathrm{~cm}$ in diameter.

\section{Solanum elaeagnifolium Car.}

Habit: Wild and annual small herb, very rare 20 to $30 \mathrm{~cm}$ in height. Habitat: Mesophyte found only at Coimbatore of Tamilnadu at an elevation of 700 to 800 feet from MSL. Stem: Woody and more branched forming a bushy appearance, cylindrical. Leaves: Oblong lanceolate (narrow and long like the leave of Elaeagnum), upper surface, light green, Lower surface with white tomentum. Inflorescence: Axillary cyme; Blue flowers. Flowers: Actinomorphic, large bisexual, bright blue and attractive. Calyx: 5, lobes, gamosepalous, valvate, green. Corolla: 5, lobes, gamopetalous, plicate, bright blue. Androecium: 5, stamens, epipetalous. Gynoecium: Bicarpellary, syncarpous, superior ovary with axile placentation. The ovary is obliquely oriented. Fruit: Globose berry, yellow. Seeds: minute, grey and compressed.

\section{Solanum melongena $\mathbf{L}$.}

Habit: Erect herbaceous, cultivated. Habitat: Mesophyte. Stem: Cylindrical, woody closely coved with short prinkles or in some cultivated forms completely unarmed, erect. Leaves: Petiolate, ovate, large elliptic $10-18 \mathrm{~cm}$. Inflorescence: Clustered cymose. Flowers: Pinkish, actinomorphic, bisexual. Calyx: 5, gamosepalous, persistant. Corolla: 5, gamopetalous, lanceolate, pinkish red coloured. Androecium: 5 stamens, epipetalous. Gynoecium: Bicarpellary, syncarpous, bilocular superior ovary with axile placentation. Fruit: Berry, glabrous, dark purple.

\section{Solanum tuberosum L.}

Habit: Perennial herb, cultivated. Habitat: Mesophyte. Stem: Woody, erect, branched, and cylindrical. Leaves: Alternate, petiolate, subelliptical, unequal at the base, acuminate. Inflorescence: Raceme Flowers: Pedicellate, Bisexual, hypogynous, actinomorphic, flowers that are pink, white or purple. Calyx: 5 lobes, gamosepalous, persistant. Corolla: 5 lobes, white; gamopetalous. Androecium: 5, stamens yellow in colour, filaments short, longitudinally. Gynoecium: Bicarpellary, syncarpous, superior ovary. The ovary is situated in oblique pattern. Fruit: Berries.

\section{Withania somnifera Dun.}

Habit: Unarmed small shrub,wild. Habitat: Mesophyte; in Hill station at an elevation of 1000 to 8000 kilometer. Stem: Woody, erect, much branched with minute stellate tomentose hairs. Leaves: Alternate, petiolated, having stellate - tomentose hairs, broadly ovate. Inflorescence: Axillary fascicles. Flowers: Shortly pedicellated, Bisexual, hypogynous, actinomorphic. Calyx: 5 lobes, accrescent and subglobose in fruit, campanulate. Corolla: 5, short, campanulate, gamopetalous. Androecium: 5, very short anthers, attached near the base of the corolla; anthers dehiscing longitudinally. Gynoecium: Bicarpellary, syncarpous, superior ovary with axile placentation. Fruit: A red globose berry, enclosed in the enlarged calyx. 


\section{DISCUSSION AND CONCLUSIONS}

Generally, the family is herbaceous or woody. Many plants in the family are economically important. Products include potato and egg plants (Solanum species) and tomato (Lycopersicon esculentum L.). Edible fruits can be found in the genus Physalis (Cape gooseberry, Jam berry, Sugar jerry, Chinese Lantern etc.) according to the species and variety. Capsicum (Sweet and chilli peppers). Etc. Most produce poisonous alkaloids and some are commercially important in this connection (Nicotiana, Datura). The taxonomic value of morphology is well documented in botanical literature, Dilcher (1974), Jayeola et al., (2001), Adedeji and Faluyi (2001), Adeeji (2004) and Adedeji and Illoh (2004). Metcafe and Chalk (1950) gave some description of the general morphology of the family Solanaceae. Since then there has been no additional anatomical work on the family in Nigeria.

The Solanaceous food can be often found in our stores as potatoes, tomatoes and chilli varieties, eggplant, and tomatillos. It was considered to be very valuable culinary vegetables. The vegetable is used in both urban and rural areas, but since it is often bitter it is mixed with Solanum species or with other green leafy vegetables. Many species of Solanaceae produce tropane alkaloids that have valuable medicinal properties. Examples include Datura stramonium, Datura fastuosa.

Nicotine is a tropane alkaloid. It makes a great insecticide. Example Nicotiana tobaccum. The family also includes many ornamental species which include Cestrum species; some others found as weeds. Examples include species of Solanum seaforthianum.

Potatoes contain toxic compounds known as glycoalkaloids, of which the most prevalent are solanine and chaconine. Solanine is found in other plants of the family Solanaceae, like the Black nightshade (Solanum nigrum), as well as the potato, eggplant, and tomato.

Among the immature vegetables, Solanum melongena and Solanum tuberosum, Capsicum frutescens, Capsicum annuum occupy a major area in cultivation in Tamilnadu. The fruit of Solanum melongena known for its low calories has a beneficial mineral composition for human health rich in source of Pottassium, Magnesium, Calcium and Iron Gbile and Adesina (1984). Unripe fruit of egg plant primarily used as cooking vegetable Guri et al., (1988) is grown as an annual crop. It has many medicinal values and its fruit helps to lower the blood cholesterol levels, and is suitable as a part of a diet to help regulate high blood pressure Goodspeed, (1933); Acosta et al., (2005).

The black nightshades family members are Solanum sisymbriifolium, Solanum seaforthianum, Solanum torvum, Solanum nigrum, Withania somnifera and related species are worldwide weeds of arable land, gardens, rubbish tips, soils rich in nitrogen, in moderately light and' warm situations which occur from sea to mundane levels. They are, however, also widely used as leafy herbs and vegetables, as a source of fruit and for various medicinal purposes.

Leaves and tender shoots are widely used and have provided a food source since early times, with Solanum trilobatum being recorded as an ancient famine plant Acosta et al., (2006); Guerra, (2000). The leaves and young shoots are boiled or stewed and used as a relish. They are also used in soups and sauces such as palaver.

Brugmansia arborea is grown in Hill station as an important ornamental plant for its long, white, pendulous and tubular flowers and is also found in a wild condition. Most of the plants like Solanum melongena, Solanum torvum, Solanum tuberosum, are grown for vegetables. Other plants like Solanum nigrum, Solanum trilobatum, Solanum xanthocarpum, and Withania somnifera are cultivated for medicinal value species. 


\section{References}

[1] Acosta M. C., Bernardello G., Guerra M., Moscone E., Taxon 54 (2005) 713-723.

[2] Acosta M. C., Ordoñez A. V., Cocucci A. A., Moscone E. A., Annals of the Missouri Botanical Garden 93 (2006) 634-646.

[3] Adedeji O., J. O. Faluyi, New Botanist 28 (2001) 145-167.

[4] Adedeji O., Botanica Lithuanica 10 (2004) 121-123.

[5] Adedeji O., H. C. Illoh, New Botanist 31 (2004) 141-180.

[6] Dilcher K. L., Bot. Rev. 40 (1974) 2-157.

[7] Gbile Z. O., S. K. Adesina, Fitoterapia 56(1) (1984) 11-15.

[8] Guri A., A. Levi, K. C. Sink, Gen. Genet. 212 (1988) 191-198.

[9] Goodspeed T. H., Proc. Natl. Acad. Sci. U.S.A. 19 (1933) 649-653.

[10] Guerra M., Genetics and Molecular Biology 23 (2000) 1029-1041.

[11] Jayeola A. A., J. R. Thorpe, J. A. Adenegan, Feddes Repertorium 112 (2001) 349-356.

[12] Metcalfe C. R., Chalk (1950). Anatomy of the Dicotyledons, Vol. 1, Oxford.

[13] E. Sanjai Gandhi, A. Sri Devi, L. Mullainathan, International Letters of Natural Sciences 5 (2014) 18-23.

[14] L. Mullainathan, A. Sridevi, S. Umavathi, E. Sanjai Gandhi, International Letters of Natural Sciences 6 (2014) 1-8. 